\title{
IT Professionals' Personality, Personal Characteristics, and Commitment: Evidence from a National Survey
}

\author{
Javaid Syed ${ }^{1} \&$ Ruth M. Tappin ${ }^{2}$ \\ ${ }^{1}$ Salem University, Salem, WV, United States \\ ${ }^{2}$ R.M.Tappin Consulting, LLC, Barrington, N. H., United States \\ Correspondence: Javaid Syed, Program Chair, Department of Computer Science \& Information Technology, 223 \\ West Main Street, Salem, WV, 26426, United States.
}

Received: April 18, 2019

Accepted: May 4, 2019 Online Published: July 25, 2019

doi:10.5539/cis.v12n3p58

URL: https://doi.org/10.5539/cis.v12n3p58

This research was not financed or sponsored by any academic, corporate, or governmental agency or entity.

\begin{abstract}
Drawing on personality traits theory (Costa \& McCrae, 1985) and organizational commitment theory (Mowday, Steers \& Porter, 1979), the purpose of the present study was to investigate, through four separate hierarchical regression procedures, the effect of a set of independent variables (neuroticism, gender, and generational age) on four separate dependent variables (DV): overall organizational commitment (OC), affective commitment (AC), continuance commitment (CC), and normative commitment (NC). The sample consisted of responses from 279 IT professionals in the United States, drawn from a national sample from the merged cross-sectional GSS 1972-2014 Cross-Sectional Cumulative Data, Release 5, March 24, 2016. Results of multiple regressions analyses revealed that, among IT professionals, neuroticism did not predict overall OC, AC, CC, or NC. Generational age predicted OC, AC, and CC with statistical significance. Gender predicted CC; none of the independent variables (IVs) predicted NC. Directions for future research are offered.
\end{abstract}

Keywords: affective commitment, age, continuous commitment, gender, general social survey, GSS, information technology, stress, neuroticism, normative commitment, organizational commitment, personal characteristics

\section{Introduction}

Information technology (IT) is one of the most critical sectors globally (Guha \& Chakrabarti, 2014). Information technology professionals play a crucial role in protecting the organization's sensitive data by shaping, maintaining, and implementing IT security measures (Jiang, 2014; Luftman \& et al., 2013). However, the IT line of work is fraught with stress, which has been identified as a contributor to high employee turnover and lack of organizational commitment in the field (Lounsbury, Sundstrom, Levy, \& Gibson, 2014; Padma \& et al., 2015). Work overload and overly demanding management expectations contribute to stress among IT workers (Lounsbury \& et al., 2014). In addition to stress, IT professionals experience very high levels of exhaustion (DePasquale \& et al., 2015; Hsieh, 2004; Kim \& Wright, 2007); 90\% of IT professionals asserted this condition affects their health (Savvas, 2004; Padma \& et al., 2015). The ability or inability to handle stress has been a predictor of job satisfaction (Hoboubi, Choobineh, Ghanavati, Keshavarzi, \& Hosseini, 2017); in turn, job satisfaction has long been a predictor of employee organizational commitment (e.g. Porter, Steers, Mowday \& Boulian, 1974; Spector, 1997).

Due to the high turnover rate in the IT field, organizations face a persistent problem with staffing and retaining IT professionals (Ertürk, 2014; Gaylard, Sutherland, \& Viedge, 2005; J.J. Jiang, Klein, \& Carr, 2002). Turnover is a known indicator of no or low organizational commitment (Allen \& Meyer, 1990). The high turnover rate in the industry seems to suggest low organizational commitment among IT workers (Ertürk, 2014; Lounsbury \& et al., 2014). Job stress was a primary reason IT professionals wanted to quit their jobs (Shropshire \& Kadlec, 2012) yet, Major, Morganson, and Bolen (2013) found no relationship between job stress and OC.

Low organizational commitment and turnover is of grave concern to organizations as the costs to replace a 
departing employee are high (Chakrabarti \& Guha, 2016). Employee replacement costs can range from 33\% to $150 \%$ of that worker's annual salary (Hancock, Allen, Bosco, McDaniel \& Pierce, 2013; Krol, Brouwer \& Rutten, 2013; James \& Mathew, 2012; Ruyle, 2012). Therefore, organizational leaders have a vested interest in reducing employee replacement costs, improving their IT staffing and retention capabilities, and generating stronger organizational commitment among these employees. The costs related to replacing departing employees demand a right fit between IT workers and the organization if organizations are to retain talented IT workers. In assessing employees' fit with the organization, it is beneficial to assess their overall organizational commitment, the different dimensions of OC influencing the employee, as well as factors that contribute to OC.

\subsection{Organizational Commitment (OC)}

One of the most important psychological constructs in organizational studies is OC. Organizational commitment has been described as a psychological state that informs the relationship between the organization and the employee, and is expressed as a decision to stay with the organization. Farrukh, Ying, and Mansori (2017) cited extant literature that revealed links between OC and a wide variety of employee behaviors, including turnover. Mowday \& et al. (1979) defined overall OC as "the relative strength of an individual's identification with, and involvement in, a particular organization" (p. 226). However, there are many conceptualizations of OC (Allen \& Meyer, 1990). Meyer and Allen (1991) conceptualized OC as a tri-dimensional construct made up of affective (emotional) commitment, normative commitment, and continuance commitment. Early research showed that there was a relationship between the occupation, employee intention to leave the organization, and OC (Meyer, Allen, \& Smith, 1993). Nevertheless, results of recent research seem to suggest that lack of OC might not be the driving force in turnover among IT employees; rather, it might be the job itself (e.g., Lounsbury \& et al., 2014).

Affective commitment (AC) is the emotional kinship that the employee feels toward the organization, and organizations prize this type of commitment above all others (Meyer \& Allen, 1997). Emotionally committed employees feel that the values of the organization are similar to their own; as a result, these employees take pride in the organization, and exhibit a willingness to work harder for the organization beyond the normal requirements of their job (Meyer \& Allen, 1997); affective commitment might to be at the core of OC (Mercurio, 2015). Antecedents of AC include the employee's perceptions of fair treatment by the organization, job autonomy, and feelings of competence regarding work (Stinglhamber \& et al., 2015); among these, the relationship between the employee and the employer-employee is a driving force behind employees' emotional commitment to the organization. Üngüren and Ehtiyar (2016) reported results that showed management style and manager satisfaction were highly correlated to affective commitment. As it relates to IT, manager style can contribute to stress among IT employees as results of extant research showed that demanding managers and unrealistic management expectations contributes to job stress (Lounsbury, 2014) and job satisfaction. Diminished AC affects employees' affective commitment (Mercurio, 2015).

Employees' continuance commitment (CC) is least desired by organizations (Üngüren \& Ehtiyar, 2016); it is the employee's strong intention to keep on working with the organization, after evaluating the results of cost- $v s$-benefit calculations of leaving the company, or availability of alternative employment (Allen \& Meyer, 1996; Meyer \& Allen, 1991). In this case, even if the employee wishes to work elsewhere, after weighing the cost of leaving the company, the employee might decide that leaving could be too great a price to pay to leave. Some of the costs-to-benefit considerations might include, for example, loss of prestige gained from employment with a prominent firm, loss of status, or lower pay and less benefits. Üngüren and Ehtiyar (2016) reported results that showed working conditions and management style had the highest negative correlations with CC. Results from earlier studies indicated that CC was highly correlated with stress, lower life satisfaction, and work family conflict (Meyer, Stanley, Herscovitch, \& Topolnytsky, 2002; Vandenberghe \& et al., 2009)

Normative commitment (NC) relates to the employee's strong feeling of obligation to stay with the company (Meyer \& Allen, 1997); this sense of obligation might have been stimulated by gratitude for some act of accommodation or kindness shown to the employee by the organization, or by the employee's belief in their value to the organization. There are statistically significant high correlations between NC and management style and manager satisfaction, and development/promotion opportunities (Üngüren \& Ehtiyar, 2016). Genevičiūtè-Janonienè and Endriulaitienè (2014) reported negative correlations between CC, NC, and propensity to turnover, which is indicative of low organizational commitment.

A wide range of factors affect OC; some these are age, gender, and job stress (Mathieu \& Zajac), and personality traits (Lounsbury \& et al., 2014; Morrow, 1993). There is an established link between stress and one personality trait in particular, neuroticism (the polar opposite of which is emotional stability). Neuroticism is associated with the inability to handle stress. However, despite the high turnover rate in the IT sector, there is little research on 
neuroticism (or emotional stability) and personal characteristics in relation to organizational commitment and its dimensions. Consequently, there is a paucity of literature on the relationship between neuroticism, gender, age, and $\mathrm{OC}$ in the IT field.

\subsection{Personality Traits}

The American Psychological Association (APA, 2014) describes human personality as relatively stable patterns of emotions, thoughts, and behavior. Personality affects the behaviors of human beings in a variety of contexts, and has been widely studied in relation to organizational outcomes. Some of these personality traits-related studies involved constructs such as job satisfaction, work motivation, stress, job commitment, and organizational commitment-among many others. Personality traits can predispose employees to higher or lower attitudes toward OC (Syed, Saeed, \& Farrukh, 2015); however, it is not possible to observe personality traits directly. Nevertheless, from an individual's behavior, one can infer the presence of certain traits, based on their attitudes (Alina \& Bernard, 2011). Personality traits stabilize with age and can account for differences in human behavior (Allport, 1927; Uher, 2013). The universality and stability of personality traits among human beings is well-established in the psychology literature (e.g., Cattell, Marshall, \& Georgiades, 1957; Galton, 1884; Goldberg, 1990; McCrae \& Costa, 1997; Thurstone, 1934; Tupes \& Cristal, 1992). Although there are various arrangements of personality traits into hierarchical levels, the Big Five Factor Model (BFFM) of personality traits theory is the most popular taxonomy of traits used in research (Allik \& McCrae, 2004; Goldberg, 1993; McCrae \& Costa, 1997).

\subsection{The Big Five Factor Model (BFFM)}

The basic tenet of the BFFM is that the vast numbers of personality traits cluster under five broad domains of personality, which are: extraversion, agreeableness, conscientiousness, emotional stability (vs. neuroticism), and intellect (or openness), arranged in hierarchical order (Goldberg, 1992; McCrae \& Costa, 1997); the definitions of the five domains of the BFFM are as follows:

1. Extraversion: energetic, socially outgoing, talkative, assertive vs. reserved;

2. Agreeableness: affectionate, kind, sympathetic, cooperative, non-confrontational, trusting vs. detached, analytical);

3. Conscientiousness: disciplined, focused, thorough, organized, plan-focused, dependable $v s$. disorganized, careless;

4. Neuroticism: associated with tenseness, moodiness, anxiety, inability to handle stress vs.emotional stability (even-tempered, ability to handle stress, thriving);

5. Openness (also referred to as Intellect): creative, insightful, imaginative, open to new experiences and new learning, clever, witty, resourceful vs. cautious. (Costa \& McCrae, 1987)

These broad dimensions of personality traits are "important psychological characteristics" (Parks-Leduc, Feldman, \& Bardi, 2014, p. 3) that predict various types of outcomes. Studies of personality traits ranged across nationalities and industries; these studies were in relation to a variety of organizational outcomes, including job satisfaction (Bui, 2017; von Rimscha, 2015), work stress, depression, and anxiety (Gramstad, Gjestad, \& Haver, 2013; Ozutku \& Altindis, 2011), turnover intentions (Jeswani \& Dave, 2012), and organizational commitment (Farrukh \& et al., 2017; Suman \& Srivastava, 2012). Nevertheless, there is little research on personality traits in the tech industry; consequently, there have been calls in the IT literature for further research on IT personnel's personological attributes (such as personality traits) and employee characteristics (such as age, gender, tenure) in relation to various organizational outcomes, including OC (e.g., Kanwar, Singh, \& Kodwani, 2012; Li, Li, Hao, Guan, \& Zhu, 2014; Lounsbury \& et al., 2014; von Rimscha, 2015). Lounsbury \& et al. (2014) recommended further research on the neuroticism/emotional stability factor in relation to stress in the IT industry sector. The focus of the present research is on the neuroticism trait relative to overall $\mathrm{OC}, \mathrm{AC}, \mathrm{CC}$, and $\mathrm{NC}$.

\subsubsection{Neuroticism (i.e., Low Emotional Stability)}

Job stress is characteristic of IT occupations. The inability to manage stress has been associated with the personality trait factor, neuroticism. Neuroticism is expressed in high levels of stress and negative emotions (Goldberg, 1990, 1993; McCrae \& Costa, 1997; McCrae \& John, 1992), and individuals with high work stress levels have been identified with neuroticism (Sharma \& Devi, 2011). In a 1999 study, sample size $n=92$, Furnham, Forde, and Ferrari reported that neurotics were much more highly influenced by the physical and psychological conditions in which they worked, which are described as hygiene factors (Herzberg, Mausner, \& Snyderman, 1959). Some of these factors have to do with work conditions, relationship with supervisor and peers, salary, benefits, and company policies and concern the context in which the job is performed (Furnham, Petrides, Jackson, \& Cotter, 2002, p. 1326). Earlier, Mathieu and Zajac (1990) identified these and other job 
characteristics as contributors to OC. These characteristics include intrinsic (internal to the employee) and extrinsic (external) conditions that influence job satisfaction as important contributors to OC. Some of these are: leadership style, job level, job skill/autonomy, and role stress (e.g., role ambiguity, role conflict, role overload). According to Mathieu and Zajac, employees can experience role stress away from work as well. More recently, Khiavi, Dashti, and Mokhtari (2016) reported a high correlation between neuroticism and CC.

In contrast to other occupations, IT professionals showed significantly lower mean scores on emotional stability (Lounsbury \& et al., 2014); low ES is indicative of high neuroticism. Lounsbury \& et al. noted that it did not seem that ES was a factor that led to job attraction, or organizational fit, among IT workers; instead, it seemed to be a consequence of the IT work. The authors reiterated that personality traits in adults are stable; however, they cautioned that there might be an exception to the ES trait for, given the manner in which researchers typically measure ES, it can reflect conditions such as the IT worker's current state of stress, worry, strain, and anxiety. In a U.S. study, Major \& et al. (2013) reported no significant relationship between job stress and OC; however, job stress was related to occupational commitment. From these studies, one inference might be that while the ability to handle stress affects the IT professional's job/occupational commitment, it does not seem to affect his or her commitment to the organization itself; therefore, we proposed the following null hypotheses that, among IT professionals:

$\mathbf{H}_{01}$ : Neuroticism is not related to overall organizational commitment.

$\mathbf{H}_{\mathbf{0 2}}$ : Neuroticism is not related to affective commitment.

$\mathbf{H}_{\mathbf{0 3}}$ : Neuroticism is not related to continuous commitment.

$\mathbf{H}_{\mathbf{0 4}}$ : Neuroticism is not related to normative commitment.

\subsection{Personal Characteristics}

Employee characteristics are among essential contributors to organizational commitment (Khiavi \& et al; Mathieu \& Zajac, 1990), and can affect employees' response to stress (Sharma \& Devi, 2011). Mathieu and Zajac (1990) listed age, gender, education, work ethics, and perceived competence as key contributors to OC. Studies on employee characteristics such as age and gender relative to OC across industries continue to produce mixed results. Previous research shows that personal characteristics such as age (including generational differences), and gender account for differences in levels of work stress (e.g., Hsieh, 2004; Lu \& Gursoy, 2012), which suggest varying expressions of the neuroticism/emotional stability trait among employees, and their ability to manage stress. Additionally, economic, political, and social conditions are some stressors that can affect male and female employees of different generational cohorts in the workplace (Jena, 2016); these influences can influence employees' commitment to their organization.

\subsubsection{Gender}

Gender may affect employees' perception of the workplace; these perceptions could inform their attitudes toward the organization (Shine, Gidwani, Birthare, \& Singh, 2015). Results of some early studies on the relationship between gender and $\mathrm{OC}$ in various industry sectors were that women were more committed to their organizations than men (e.g. Cramer,1993; Genevičiùtė-Janonienè, \& Endriulaitienè, 2014; Mathieu \& Zajac, 1990; Mowday \& et al.,1982); however, other studies produced opposite results (e.g. Billingsley \& Cross, 1992; Eleswed \& Mohammed, 2014; Shine \& et al., 2015). For decades the presence of women in the workplace has been increasing; however, despite growing demand for IT workers, there is an underrepresentation of women in the IT field (Major \& et al., 2013). Sexism, discrimination, lack of flexibility, and lack of advancement opportunities in the male-dominated IT field were found to be contributing stress factors that account for the low representation of American women in the IT profession (Chen, de la Mora, \& Kemis, 2017).

Finding from extant studies showed that there was no significant difference between men and women in relation to OC. Results of meta-analyses indicated no relationship between gender and commitment, and women working in fields typically dominated by males showed no statistically significant difference in OC, compared to males (Major \& et al., 2013). However, in the IT field, the turnover rate for women is $50 \%$ higher than that of males (Dubow, 2010), which might indicate a lack of commitment among women; all in all, the effect of gender on OC is still not clear. Major \& et al. (2013) studied predictors of occupational and organizational commitment among men and women in IT compared to other industry sectors; the predictors included job stress, growth satisfaction, job security satisfaction, and work-family culture. Findings from the study showed that, among IT professionals, job stress did not predict OC; however, they found that it was a significant predictor for occupational commitment. Additionally, job stress weighted more strongly for men than for women. This seems to suggest two things: first, while commitment to the job itself might deteriorate, commitment to the organization could 
remain strong and, secondly, women in the IT field might be better able to handle job stress than men; yet, this inference might be flawed given the high turnover rate among women in the IT field. Non-U.S studies also seemed to show mixed results.

In India, women comprise $34 \%$ of the IT workforce; in contrast, as of 2017 , only $27 \%$ of professional IT positions in the U.S. were held by women (National Center for Women and Information Technology, 2017). In a gender-diversified Indian context, Kanwar \& et al. (2012) reported that job satisfaction and OC was higher among men than among women in IT. The differences in the American and Indian studies might be due to social and cultural considerations. Nevertheless, due to the paucity of studies in the IT literature on personological attributes and personal characteristics of IT workers, there is a lacuna in the literature in this area (Bartol, 1983; Lounsbury \& et al., 2014). Based on the preceding information, we proposed the following hypotheses:

$\mathbf{H}_{\mathbf{0 5}}$ : Gender is not related to overall organizational commitment.

$\mathbf{H}_{\mathbf{0 6}}$ : Gender is not related to affective commitment.

$\mathbf{H}_{\mathbf{0 7}}$ : Gender is not related to continuous commitment.

$\mathbf{H}_{\mathbf{0 8}}$ : Gender is not related to normative commitment.

\subsubsection{Age}

A generational cohort is a group of peers who were born around the same time period and go through similar life experiences that might be related to historical or social events. These events cause a peer group to exhibit unique characteristics that are distinct from other peer groups born at different times, and exposed to different historical and social events. Generational cohorts are recognized by the age range into which they fall. For example, Gen Y range in age from $18-35$ yrs; Gen X, $36-53$ yrs., and Baby Boomers $54-69$ yrs. In the literature, there is no consensus on the relationship between age and OC. Commitment increased with age (Mathieu \& Zajac, 1990); and age was significantly related to OC, CC, and NC (e.g., Jena, 2016; Sikorska-Simmons, 2005). However, results from Suman and Srivastava (2012) and Eleswed and Mohammed (2014) were that age had no statistically significant effect on OC. Age was the dominant employee characteristic related to job satisfaction and OC, with negative job satisfaction and OC attitudes predominating among employees aged 18 to 27 and married males aged 28 to 37 (Üngüren \& Ehtiyar 2016); older workers tended to be more committed (Bureau of Labor Statistics [BLS], 2016). Age is one of the considerations that pertain to emotional stability and job satisfaction. There is a belief that Millennials (i.e., between 18 and 31) have unrealistic expectations about the IT workplace (James \& Mathew, 2012; Krol \& et al., 2013), which might account for lack of commitment among this group. The GenY generation exhibited higher NC to the organization than GenXers; however, the GenX generation had a higher CC to the organization than GenY (Jena, 2016). The inconsistent reports on the relationship between age and $\mathrm{OC}$ prompted the following hypotheses:

$\mathbf{H}_{\mathbf{0}}$ : Generational age is not related to overall organizational commitment.

$\mathbf{H}_{\mathbf{0 1 0}}$ : Generational age is not related to affective commitment.

$\mathbf{H}_{011}$ : Generational age is not related to continuous commitment.

$\mathbf{H}_{\mathbf{0 1 2}}$ : Generational age is not related to normative commitment.

\section{Method}

\subsection{Overview}

Used in the present study were archival data from the General Social Survey (GSS) public domain national database. The National Data Program for the Social Sciences of the National Opinion Research Center (NORC) at the University of Chicago funds the GSS data collection, which focuses on collecting data on social issues and trends in America every two years. After selecting out other occupations from the dataset, and based on the U.S. BLS classifications, the sample frame was the responses from the population of U.S. respondents in the GSS 1972-2014 Cross-Sectional Cumulative Data, Release 5, March 24, 2016 dataset, described in the dataset as "Computer Systems Analysts" (CSA) and "Scientists and Operations Systems and Research Analysts", also referred to as Systems Analysts (SA).

\subsection{Participants}

The sample consisted of responses from male $(n=138)$ and female $(n=141)$ survey participants in the CSA and SA fields $(n=279)$, employed at the time of the survey. The age range of respondents was $18-71$ years, stratified according to three generational cohorts: Gen Y; Gen X, and Baby Boomers. The use of archival data from the GSS eliminated ethical concerns for this study regarding research with human beings. Results from a 
G*Power 3.1.9.2 sample calculation (Faul, Erdfelder, Land, \& Buchner, 2012) indicated that the minimum sample size required to detect an effect in the population would be 119; however, the reduced sample size was larger than $119(n=279)$. A post hoc calculation revealed that the power of the present sample size of 279 to detect a statistically significant effect in the sample was 0.9999 . Of the 279 participants, $49.5 \%$ were males $(n=$ 138). By age group, relative frequencies were GenY $(18-35), 45.2 \%(n=126)$; GenX $(36-53), 43.4 \%,(n=$ $121)$, and Baby Boomers $(54-69), 11.5 \%(n=32)$. By racial composition, Whites $=85.7 \%(n=239)$, Blacks $=$ $10 \%(n=28)$, and "other" $=4.3 \%(n=12)$. Most participants held a high school degree $(50.2 \%, \mathrm{n}=140)$, and $5 \%$ $(n=4)$ were junior college level educated (Table 1).

Table 1. Age, Gender, Education

\begin{tabular}{lll}
\hline Value & Count & Percent \\
\hline Age & & \\
$18-35$ (GenY) & 126 & $45.2 \%$ \\
$36-53$ (GenX) & 121 & $43.4 \%$ \\
$54-69$ (Baby Boomers) & 32 & $11.5 \%$ \\
Gender & & \\
Female (0) & 141 & $50.5 \%$ \\
Male (1) & 138 & $49.5 \%$ \\
Education & & \\
LT high school & 25 & $9.0 \%$ \\
High school & 140 & $50.2 \%$ \\
Junior college & 14 & $5.0 \%$ \\
Bachelor & 70 & $25.1 \%$ \\
Graduate & 30 & $10.8 \%$ \\
\hline
\end{tabular}

Note: $n=279$, female coded "0", male coded " 1 ".

Geographically, the majority of respondents were from the Middle Atlantic regions of the U.S. (Table 2).

Table 2. Region

\begin{tabular}{lllll}
\hline & & Value & Count & Percent \\
\hline \multirow{2}{*}{ Valid Values } & & & & \\
& 1 & New England & 36 & $12.9 \%$ \\
& 2 & Mid Atlantic & 87 & $31.2 \%$ \\
& 3 & E. North Central & 44 & $15.8 \%$ \\
& 4 & W. North Central & 17 & $6.1 \%$ \\
& 5 & South Atlantic & 26 & $9.3 \%$ \\
& 6 & E. South Central & 0 & $0.0 \%$ \\
& 7 & W. South Central & 22 & $7.9 \%$ \\
Missing Values & 8 & Mountain & 0 & $0.0 \%$ \\
& 9 & Pacific & 47 & $16.8 \%$ \\
\hline
\end{tabular}

$n=279$

\section{Measures}

The GSS dataset used for the present research contained a bundle of six items that gather data on each of the variables that measure the three dimensions of the organizational commitment (OC) construct. Table 3 shows the dependent variables (DV), their operationalized definitions, items as labeled in the GSS dataset, and sources used in this study. 
Table 3. Organizational Commitment Scale

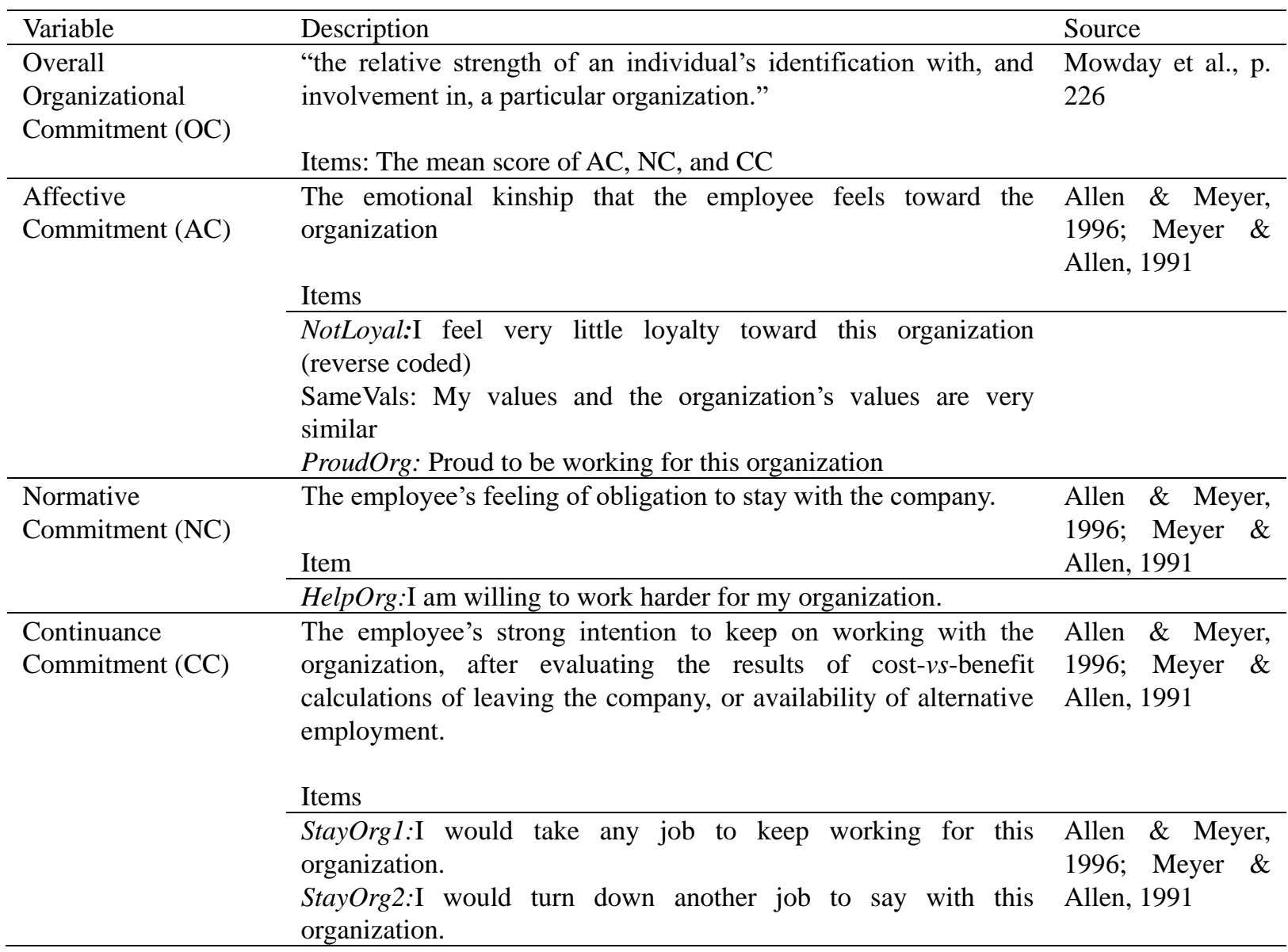

On a five-point Likert-type scale, responses were weighted as $1=$ strongly agree, $2=$ agree, $3=$ neutral (don't know), 4 = disagree, 5 = strongly disagree. Calculations across the six items produced the average OC score. Scale reliability for this study was $\alpha=.796$. Data analysis was with SPSS. The six items measuring OC were used in a study by Marsden, Kalleberg, and Cook (1993, p. 376) and, according to Marsden et al., correspond with the item wording shown on page 75 in the 1990 Indianapolis/Tokyo Work Commitment study by Lincoln and Kalleberg. These items measured the three dimensions of OC.

\subsection{Neuroticism}

10 items in the GSS dataset measure the Big 5 personality traits; two items measure each personality trait. These items reflect the Rammstedt and John (2007) 10-item Big Five inventory scale (BFI-10) abbreviated from the 44-item BFI inventory (BFI-44) developed by Costa and McCrae (1985). Compared to the NEO-PI-R scale (Costa \& McCrae, 1985), the BFI-10 scale retained considerable levels of the reliability and validity of the 44-item scale (Rammstedt \& John, 2007). In the GSS dataset, the following two items measured the neuroticism dimension of the BFFM:

Big5d1: R[espondent] sees oneself as being relaxed (reverse scored)

Big5d2: R[esponent] sees oneself as someone who gets nervous easily

On a five-point Likert-type scale, responses were weighted as 1= strongly agree, $2=$ agree, $3=$ neither agree nor disagree, 4 = disagree, 5 = strongly disagree. After a reverse-scoring procedure, a composite score was obtained to produce an average neuroticism score; this was renamed neuroticism_averaged. 


\section{Results}

Examination of the research question was by application of multiple regressions analyses in which a hierarchical procedure was used to enter the variables into the regression equation sequentially (Tabachnick \& Fidell, 2013). Table 4 represents the means and standard deviation for the continuous variables.

Table 4. Mean, Standard Deviation

\begin{tabular}{lll}
\hline Variable & Mean & SD \\
\hline DV - Overall Organizational Commitment (OC) & 2.51 & .839 \\
DV - Affective Commitment (AC) & 2.19 & .91 \\
DV - Continuance Commitment (CC) & 3.29 & 1.16 \\
DV - Normative Commitment (NC) & 1.92 & .98 \\
IV - Neuroticism (N) & 3.64 & .879 \\
IV - Age 18-35 (GenY) & .45 & .499 \\
IV - Age 36-53 (GenX) & .43 & .496 \\
IV - Age 54-71 (Boomer) & .11 & .319 \\
\hline
\end{tabular}

Note: $n=279$

\subsection{Overall Commitment (OC)}

For each of the IVs tested, three summary models were obtained. For example, in regressing the three IVs against the DV (OC), when entered sequentially, the following summary Models were produced: Model $1=$ neuroticism vs. OC; Model $2=$ neuroticism + gender, vs. OC, and the full model, Model $3=$ neuroticism + gender + generational age vs. OC. Neither neuroticism (Model 1) nor the addition of gender into the regression equation (Model 2) predicted OC ( $p>.05)$.

Altogether, the addition of the three levels of generational age (GA) to the prediction of OC (Model 3) improved the model and led to a statistically significant increase in $R^{2}$ of $.047(R$-square Change $=.038)$, explaining $3.8 \%$ of the variation in OC, $F(2,274)=5.498, p=.005, p<.05$. Neither the GenY (18-35) nor GenX age (36-53) groups contributed to the prediction of OC; however, for every additional unit or additional year of the Boomer generation (54-69), there was a $.511(51.1 \%)$ decrease in OC $(b=-.511, p=.002, p<.05)$. Based on results from the ANOVA output, the full model of neuroticism, gender, and GA to predict OC (Model 3) was statistically significant, $R=.218, R^{2}=.047, F(4,274)=3.404, p=.010, p<.05$, adjusted- $R^{2}=.033$. Since neither neuroticism nor gender predicted OC, the null hypotheses 1 and 5 were supported $(p>.05)$. Hypothesis 9 was not supported as there was a statistically significant relationship between generational age (specifically the Boomer generation) and $\mathrm{OC}(p<.05)$; the alternative hypothesis was accepted.

\subsection{Affective Commitment ( $A C$ )}

In a similar hierarchical regression, three summary Models were produced when neuroticism (Model 1), neuroticism + gender (Model 2), and neuroticism + gender + three levels of generational age (Model 3) were regressed against AC. Once again, in Model 1 and Model 2 there were negligible and statistically non-significant correlations between the IVs and AC (Model 1, $R=.025, p=.676, p>.05$; Model 2, $R=.026, p=.936, p>.05$ ). However, the addition of the three levels of GA to the full model (Model 3) led to an improved but weak correlation between the IVs and AC $(R=.18)$ and led to a statistically significant increase in $R^{2}$ of .033 $\left(R^{2}\right.$-change $\left.=.032\right)$, explaining $3.2 \%$ of the variation in $\left.\mathrm{AC}, F(2,274)=4.544, p=.011, p<.05, R^{2}=.033\right)$. For every additional unit (i.e., year) of the Boomer generation, there was a $53.1 \%$ decrease in $\mathrm{AC}(b=-.53 .1, \mathrm{p}$ $=.003, p<.01)$. Nevertheless, based on results from the ANOVA output, the full model of neuroticism, gender, and GA to predict AC did not reach statistical significance: $R^{2}=.033, F(4,274)=2.318, p=.057, p>.05$, adjusted- $R^{2}=.019$. Null Hypotheses 2 and 6 were supported ( $p>.05$ ); however, hypothesis 10 was not supported $(p<.05)$, and the alternative was accepted.

\subsection{Continuance Commitment (CC)}

In a sequential hierarchical regression procedure, when regressed against CC (Model 1 output), there was a no statistically significant relationship between neuroticism and CC, $(R=.043, p=.474, p>$. 05). However, the addition of gender (Model 2), and three levels of GA to the equation (Model 3), led to weak but statistically significant correlations between the IVs and the DV. 
Gender. The addition of gender to the prediction of CC (Model 2) led to a statistically significant increase in $R^{2}$ of $\left..020, F(1,276)=5.580, p=.019, p<.05, R^{2}=.022\right)$. The size of the correlation between neuroticism, gender, and CC (from the Model 2 output) was very small $(R=.147)$. Gender explained $2 \%$ of the variation in CC. The predicted CC for males was $31.6 \%$ less than for females $(b=-.316)$; the null hypothesis was not supported, and the alternative was accepted.

Generational age (GA).The addition of generational age (GA) to the prediction of CC (Model 3) led to a statistically significant increase in $R^{2}$ of .035 . The size of the correlation between neuroticism, gender, and the three levels of GA and CC was small $(R=.238)$, leading to a statistically significant increase in $R^{2}$ of .035 , $\left.F(2,274)=4.544, p=.011, p<.05, R^{2}=.033\right)$. Generational age accounted for $3.5 \%$ of the variation in AC. Based on results from the ANOVA output, the full model of neuroticism, gender, and GA to predict CC reached statistical significance: $F(4,274)=4.100, p=.003, p<.05$, adjusted- $R=.043$ ). For every additional unit (i.e., year) of the Boomer generation, there was a $66.4 \%$ decrease in CC $(b=-.664, p=.004, p<.01)$. Null hypothesis 3 was supported $(p>.05)$; however, hypotheses 7 and 11 were not supported as there were statistically significant relationships between gender and CC (Model 2, $p=.019, p<.05$ ), and between gender, GA and CC, Model 3 ( $p$ $=.007, p<.01)$; the alternative hypotheses were accepted.

\subsection{Normative Commitment (NC)}

When regressed against NC, none of the IVs (i.e., neuroticism, gender, generational age) predicted NC ( $p>.05)$; therefore, the null hypotheses 4,8 , and 12 were supported.

\section{Discussion of Results}

Four separate hierarchical multiple regression procedures were applied to determine the ability of neuroticism, gender, and generational age (the IVs) to predict OC, AC, CC, and NC. Despite a recent study in which a high correlation between Neuroticism and CC was reported (Khiavi \& et al., 2016), surprisingly, in no instance did neuroticism predict $\mathrm{OC}$ or the underlying dimensions of $\mathrm{OC}$ (i.e., $\mathrm{AC}, \mathrm{CC}$, and $\mathrm{NC}$ ), despite evidence in the literature that the IT field is fraught with stress, and there is a high incidence of turnover in the IT industry due to stress related to heavy workloads, health problems, demanding managers, unrealistic expectations, and lack of job security (Lounsbury \& et al., 2014; Savvas, 2004). Results suggested an agreement with evidence in the literature that job stress did not statistically significantly predict OC; instead, while employees in the IT field might experience high levels of stress, the inability to handle stress might be related to the job itself, and not to the organization (e.g., Lounsbury \& et al., 2014; Major \& et al., 2014). In other words, commitment to the organization can remain intact even when employees' commitment to the job itself deteriorates.

Since there is a high rate of turnover in the IT sector, it might behoove managers to examine the working conditions and job characteristics that affect the work itself, and make changes and policies aimed at reducing stresses related to the job. For example, to avoid employee-burnout, managers should ensure that there is adequate coverage in the IT department so that the employee's workload is reasonable and manageable. Additionally, when the employee takes much needed time off, there should be no imposition on this sacred, rejuvenating break from work.

Gender did not predict OC, AC, or NC, although results of some studies were that men tend to be less committed to the organization than women, and $\mathrm{AC}$ was higher in women. The statistically significant relationship between gender and $\mathrm{CC}$ was interesting as this aspect of commitment has to do with cost-to-benefit analyses of deliberations about staying with the company or seeking employment elsewhere. Men were $32.6 \%$ less likely than women to exhibit CC; put in different terms, women were $32.6 \%$ more likely than men to exhibit CC. This result might offer a glimpse into why turnover among women in the IT field is so much higher than that of men; it is possible that, for women, the cost of staying in their organization might be too high a price to pay, and it might benefit them more to leave the organization. In a male dominated field in which women face issues such as sexism, lower pay, and less opportunities for advancement, women in IT might be more incentivized to look for other employment alternatives that offer better working conditions or more opportunities.

Generational age was significantly related to overall OC, with Boomers making the most contribution to the prediction of overall OC. Among this sample of IT professionals, as Boomers aged, overall, they were less committed to the organization; for every one unit increase in age among this generation, there was a $51.1 \%$ decrease in OC. This result was contrary to the ample evidence in the literature across sectors, which showed that as workers aged, their OC increased. A more granular assessment of the three dimensions of OC revealed that generational age among the Boomer generation predicted affective commitment such that for every one unit increase in age among this group, the employee's emotional commitment to the company was reduced by $53.1 \%$. In this study, the Boomer generation comprised only $11.5 \%$ of the sample. Given the predominance of younger 
employees in the field, the fast pace of change in the IT sector, and with a longer exposure to the stresses of IT work, perhaps the Boomer generation might be experiencing higher levels of job stress at this stage of their life. Generational age also predicted continuance commitment. Despite increasingly lower OC and AC among Boomers, for every additional unit of age in this group, Boomers were $66.4 \%$ less likely to exhibit continuous commitment to the organization. This result seems to agree with a 2016 BLS report that the tenure of older workers was longer than that on younger workers. Perhaps, for Boomers, when weighed in the balance, the benefits of staying with the organizations far outweighs the benefits of leaving; this might be because with each year they move closer to retirement and fewer attractive employment alternatives in IT might exist for this age group. Neither neuroticism, nor generational age, nor gender predicted normative commitment.

\section{Recommendations for Future Research}

A limitation to this study is that five-year-old self-report secondary data were used. The use of primary data might produce different results, so a replication of the study with more current data is recommended. Deeper understanding of the problem might be gained if the phenomenon were to be examined using other statistical methods, or direct observation of the IT employee in the work environment onsite. Results of this study showed that women exhibit a higher tendency to weigh the costs and benefits of staying with the organization. Further investigations might provide insight into the intrinsic and extrinsic reasons that motivate female IT workers to entertain CC deliberations in the first place. In this case, other variables should be examined, which might include (not limited to) organizational culture, sexism, various forms of discrimination, promotional opportunities, leadership style, managerial expectations, and managerial demands on IT female employees and specific characteristics of the job itself. The problem could be examined through subjective lenses to gain a deeper understanding of female IT workers lived experience in their field. Further studies might be warranted to understand why Boomers in the IT field seem to exhibit less OC, and even less AC. For example, among other variables, the role of ageism for its effect on OC and its dimensions might be examined, as well as other personal characteristics and personality variables. A closer examination of management policies and practices regarding employees' rights, and management expectations, practices and leadership styles might be warranted to gain deeper insight into the problem.

\section{Conclusions}

In agreement with the literature, results of this study showed that there is no relationship between the ability to manage stress (neuroticism) and overall OC, AC, CC, or NC in the IT field. Studies on employee characteristics such as gender and age relative to OC across industries continue to produce mixed results (e.g., Sikorska-Simmons, 2005; Suman \& Srivastava, 2012; Üngüren \& Ehtiyar, 2016); as results of this study demonstrated, this is also true for the IT industry. Given the growing importance of IT and the cost of replacing an employee, employers must make it a priority to understand the forces that drive stress because it may be the job itself (and characteristics thereof) that is fueling employees' dissatisfaction and lack of commitment, which might account for the high turnover in the IT field. Human resource policies and practices might be shaped to improve the areas or conditions that are prompting thoughts of quitting the organization in the first place, and to address the decrease in commitment among the IT Boomer generation as they age.

\section{References}

Alina, M. C., \& Bernard, G. (2011). Personological categories from spontaneous descriptions and their correspondences with the five-factor model. Procedia - Social and Behavioral Sciences, 30, 2631-2636. https://doi.org/10.1016/j.sbspro.2011.10.515

Allen, N. J., \& Meyer, J. P. (1990). The measurement and antecedents of affective, continuance and normative commitment to the organization. Journal of Occupational Psychology, 63(1), 1-18. https://doi.org/10.1111/j.2044-8325.1990.tb00506.x

Allik, J., \& McCrae, R. R. (2004). Toward a geography of personality traits: Patterns of profiles across 36 cultures. Journal of Cross-Cultural Psychology, 35(1), 13-28. https://doi.org/10.1177/0022022103260382

Allport, G. W. (1927). Concepts of trait and personality.Psychological Bulletin, 24, $284-293$. https://doi.org/10.1037/h0073629

Bartol, K. M. (1983). Turnover among DP personnel: A causal analysis. Communications of the ACM, 26, 807-811. https://doi.org/10.1145/358413.358433

Billingsley, B. S., \& Cross, L. H. (1992). Predictors of commitment, job satisfaction, and intent to stay in teaching: A comparison of general and special educators. Journal of Special Education, 25(4), 453-472. https://doi.org/10.1177/002246699202500404 
Bui, H. T. (2017). Big Five personality traits and job satisfaction. Journal of General Management, 42(3), 21-30. https://doi.org/10.1177/0306307016687990

Bureau of Labor Statistics, U.S. Department of Labor. (2016). News release: Employee tenure in 2016 (BLS Publication No. USDL-16-1867. Retrieved from https://www.bls.gov/cps/

Cattell, R. B., Marshall, M. B., \& Georgiades, S. (1957). Personality and motivation: Structure and measurement. Journal of Personality Disorders, 19 (1), 53-67. https://doi.org/10.1521/pedi.19.1.53.62180

Chakrabarti, S., \& Guha, S. (2016). Differentials in information technology professional category and turnover propensity: A study. Global Business Review, 17(3_suppl), 90S-106S. https://doi.org/10.1177/0972150916631086

Chen, Y. (April), Mora, A., \& Kemis, M. (2017). Recruiting and retaining women in information technology programs. New Directions for Community Colleges, 2017(178), 79-90. https://doi.org/10.1002/cc.20255

Costa, P. T, \& McCrae, R. R. (1985). The NEO personality inventory manual. Odessa, FL: Psychological Assessment Resources.

Cramer, D. (1993). Tenure, commitment, and satisfaction of college graduates in an engineering firm. Journal of Social Psychology, 133(6), 791-797. https://doi.org/10.1080/00224545.1993.9713940

DePasquale, N., Polenick, C. A., Davis, K. D., Moen, P., Hammer, L. B., \& Almeida, D. M. (2015). The psychosocial implications of managing work and family caregiving roles: Gender differences among information technology professionals. Journal of Family Issues, 0192513X15584680. https://doi.org/10.1177/0192513x15584680

Dubow, W. M. (2010). NCWIT scorecard: A report on the status of women in information technology. Boulder, CO: National Center for Women and Information Technology.

Eleswed, M., \& Mohammed, F. (2014).Predicting organizational commitment via job satisfaction, gender, age, experience, and position: An empirical investigation in a private financial institution in Bahrain. International Journal of Business and Social Science,5,150-158. Retrieved from http://ijbssnet.com/journals/Vol_5_No_9_1_August_2014/13.pdf

Ertürk, A. (2014). Influences of HR practices, social exchange, and trust on turnover intentions of public IT professionals. Public Personnel Management, 43(1), 140-175.https://doi.org/10.1177/0091026013517875

Faul, F., Erdfelder, E., Lang, A. G., \& Buchner, A. (2012). Statistical power analyses using G*Power 3.1:Tests for correlation and regression analyses. Behavior Research Methods, 41(4), 1149-1160. https://doi.org/10.3758/BRM.41.4.1149

Farrukh, M., Ying, C. W., \& Mansori, S. (2017). Organizational commitment: an empirical analysis of personality traits. Journal of Work-Applied Management, 9(1), 18-34. https://doi.org/10.1108/jwam-12-2016-0026

Furnham, A., Forde, L., \& Ferrari, K. (1999). Personality and work motivation. Personality and Individual Differences, 26(6), 1035-1040. https://doi.org/10.1016/s0191-8869(98)00202-5

Galton, F. (1884). Measurement of character.Fortnightly Review, 36, 179-185. https://doi.org/10.1037/11352-058

Gaylard, M., Sutherland, M., \& Viedge, C. (2005). The factors perceived to influence the retention of information technology workers. South African Journal of Business Management, 36(3), 87-97. Retrieved from https://www.ingentaconnect.com/content/sabinet/busman/2005/00000036/00000003/art00008

General Social Survey. (2015). Retrieved from http://gss.norc.org/About-The-GSS

Genevičiūtè-Janonienè, G., \& Endriulaitienè, A. (2014). Employees' organizational commitment: Its negative aspects for organizations. Procedia - Social and Behavioral Sciences, 140, 558-564. https://doi.org/10.1016/j.sbspro.2014.04.470

Goldberg, L. R. (1990). An alternative 'description of personality': The Big-Five factor structure. Journal of Personality and Social Psychology, 59(6), 1216-1229. https://doi.org/10.1037/0022-3514.59.6.1216

Goldberg, L. R. (1992). The development of markers for the Big-Five factor structure.Psychological Assessment, 4(1), 26-42. https://doi.org/10.1037/1040-3590.4.1.26

Goldberg, L. R. (1993). The structure of phenotypic personality traits.American Psychologist, 48(1), 26-34. https://doi.org/10.1037/0003-066x.48.1.26 
Gramstad, T. O., Gjestad, R., \& Haver, B. (2013). Personality traits predict job stress, depression and anxiety among junior physicians. BMC Medical Education, 13(1). https://doi.org/10.1186/1472-6920-13-150

Guha, S., \& Chakrabarti, S. (2014). Employee turnover: A study on information technology sector. Journal of Business and Management, 20(2), 71-87. Retrieved from http://www.jbm.johogo.com

Hancock, J. I., Allen, D. G., Bosco, F. A., McDaniel, K. R., \& Pierce, C. A. (2013).Meta-analytic review of employee turnover as a predictor of firm performance. Journal of Management, 39(3), 573-603. https://doi.org/10.1177/0149206311424943

Herzberg, F., Mausner, B., \& Snyderman, B. (1959).The motivation to work. (2nd rev. ed.), New York: Wiley.

Hoboubi, N., Choobineh, A., Ghanavati, F. K., Keshavarzi, S., \& Hosseini, A. A. (2017). The impact of job stress and job satisfaction on workforce productivity in an Iranian petrochemical industry. Safety and Health at Work, 8(1), 67-71. https://doi.org/10.1016/j.shaw.2016.07.002

Hsieh, H-L., Huang, L-C., \& Su, K-J. (2004) Work stress and job performance in the hi-tech industry: a closer view for vocational education. World Transactions on Engineering and Technology Education, 3, 147-150. Retrieved from http://www.wiete.com.au/journals/WTE\&TE/Pages/Vol.3,\%20No.1\%20(2004)/30_Hsieh37.pdf

James, L., \& Mathew, L. (2012). Employee retention strategies: IT industry. SCMS Journal of Indian Management, 9(3), 79. Retrieved from https://www.scms.edu.in/journal

Jena, R. K. (2016). Effect of generation gap on organizational commitment: A case study of Ferro-alloy industries in India. Global Business Review, 17(3_suppl), 76S-89S. https://doi.org/10.1177/0972150916631085

Jeswani, S., \& Dave, S. (2012). Impact of individual personality on turnover intention. Management and Labour Studies, 37(3), 253-265. https://doi.org/10.1177/0258042x13484837

Jiang, J. J., Klein, G., \& Carr, C. L. (2002).Measuring information system service quality: SERVQUAL from the other side. MIS quarterly, 145-166.https://doi.org/10.2307/4132324

Jiang, M. (2014). The business and politics of search engines: A comparative study of Baidu and Google's search results of Internet events in China. New Media \& Society, 16(2), 212-233. https://doi.org/10.1177/1461444813481196

Kanwar, Y. P. S., Singh, A. K., \& Kodwani, A. D. (2012). A study of job satisfaction, organizational commitment and turnover intent among the IT and ITES sector employees. Vision: The Journal of Business Perspective, 16(1), 27-35. https://doi.org/10.1177/097226291201600103

Khiavi, F. F, Dashti, R., \& Mokhtari, S. (2016). Association between organizational commitment and personality traits of faculty members of Ahvaz Jundishapur University of Medical Sciences.Electronic Physician, 8(3), 2129-2135. https://doi.org/10.19082/2129

Kim, S., \& Wright, B. E. (2007). IT employee work exhaustion: Toward an integrated model of antecedents and consequences. Review of Public Personnel Administration, 27(2), 147-170. https://doi.org/10.1177/0734371x06290775

Krol, M., Brouwer, W., \& Rutten, F. (2013). Productivity costs in economic evaluations: past, present, future. Pharmacoeconomics, 31(7), 537-549. https://doi.org/10.1007/s40273-013-0056-3

Li, L., Li, A., Hao, B., Guan, Z., \& Zhu, T. (2014). Predicting active users' personality based on micro-blogging behaviors.PLoS One, 9(1). https://doi.org/http://dx.doi.org/10.1371/journal.pone.0084997

Lincoln, J. R., \& Kalleberg, A. L. (1990). Culture, control, and commitment: A study of work organization and work attitudes in the U.S. and Japan. New York: Cambridge University Press.

Lounsbury, J. W., Sundstrom, E., Levy, J. J., \& Gibson, L. W. (2014).Distinctive personality traits of information technology professionals. Computer and Information Science, 7(3). https://doi.org/10.5539/cis.v7n3p38

Luftman, J., Zadeh, H. S., Derksen, B., Santana, M., Rigoni, E. H., \& Huang, Z. D. (2013). Key information technology and management issues 2012-2013: An international study. Journal of Information Technology, 28(4), 354-366. https://doi.org/10.1057/jit.2012.14

Major, D. A., Morganson, V. J., \& Bolen, H. M. (2013). Predictors of occupational and organizational commitment in information technology: Exploring gender differences and similarities. Journal of Business and Psychology, 28(3), 301-314. https://doi.org/http://dx.doi.org/10.1007/s10869-012-9282-5 
Mathieu, J. E., \& Zajac, D. M. (1990). A review and meta-analysis of the antecedents, correlates, and consequences of organisational commitment.Psychological Bulletin, 108(2), 171-194. https://doi.org/ 10.1037//0033-2909.108.2.171

McCrae, R. R., \& Costa, P. T. (1987).Validation of the five-factor model of personality across instruments and observers.Journal of Personality and Social Psychology, 52(1), 81-90. https://doi.org/10.1037/0022-3514.52.1.81

Mercurio, Z. A. (2015). Affective commitment as a core essence of organizational commitment. Human Resource Development Review, 14(4), 389-414. https://doi.org/10.1177/1534484315603612

Meyer, J. P., Stanley, D. J., Herscovitch, L., \& Topolnytsky, L. (2002). Affective, continuance, and normative commitment to the organization: A meta-analysis of antecedents, correlates, and consequences. Journal of Vocational Behavior, 61, 20-52. https://doi.org/10.1006/jvbe.2001.1842

Meyer, J. P., \& Allen, N. J. (1997). Commitment in the workplace: Theory, research,and application. Thousand Oaks, CA: Sage Publications.

Meyer, J. P., \& Allen, N. J. (1991) A three-component conceptualization of organizational commitment.Human Resource Management Review, 1(1), 61-89. https://doi.org/10.1016/1053-4822(91)90011-z

Morrow, P. (1993). The theory and measurement of work commitment. Greenwich, CT: JAI Press.

Mowday, R. T., Porter L. W., \& Steers, R. M. (1982). Employee-Organizational Linkages: The Psychology of Commitment, Absenteeism and Turnover. New York: Academic Press.

Mowday, R. T., Steers, R. M., \& Porter, L. W. (1979). The measurement of organizational commitment. Journal of Vocational Behavior, 14, 224-247. https://doi.org/10.1016/0001-8791(79)90072-1

National Center for Women \& Information Technology. (2019). NCWIT Scorecard: The Status of Women in Computing [2019 Update]. NCWIT. Retrieved from https://www.ncwit.org/resources/ncwit-scorecard-status-women-computing-2019-update

Ozutku, H., \& Altindis, S. (2011). Big five personality factors and other elements in understanding work stress of Turkish health care professionals. African Journal of Business Management, 5(26). https://doi.org/10.5897/ajbm11.2110

Padma, V., Anand, N. N., Gurukul, S. M., Javid, S. M., Prasad, A., \& Arun, S. (2015). Health problems and stress in information technology and business process outsourcing employees. Journal of Pharmacy \& Bioallied Sciences, 7(1), S9-S13. https://doi.org/10.4103/0975-7406.155764

Parks-Leduc, L., Feldman, G., \& Bardi, A. (2014). Personality traits and personal values: A meta-analysis. Personality and Social Psychology Review, 19(1), 3-29. https://doi.org/10.1177/1088868314538548

Porter, L.W., Steers, R. M., Mowday, R. T., \& Boulian, P. V. (1974). Organizationalcommitment, job satisfaction, and turnover among psychiatric technicians. Journal of Applied Psychology, 59, 603-609. https://doi.org/10.1037/h0037335

Ruyle, K. (2012, July). Measuring and mitigating cost of employee turnover. Society of Human Resource Management Webcast. Retrieved from http://www.shrm.org/multimedia/webcasts/Documents/12ruyle_2.pdf

Savvas, A. (2004). Work stress at record high. Computer Weekly, 9(7), 2004. Retrieved from https://www.computerweekly.com/news/2240057679/Work-stress-at-record-high

Sharma, J., \& Devi, A. (2011). Individual differences and stress at workplace. Asia Pacific Business Review, 7(3), 198-207. https://doi.org/10.1177/097324701100700318

Shine, D., Gidwani, R., Birthare, N., \& Singh, P. (2015). Impacts of job satisfaction and organizational commitment: A study describing influence of gender difference on job satisfaction and organizational commitment, International Journal of Core Engineering \& Management IJCEM, 2(1), 93-111. Retrieved from http://ijcem.in

Sikorska-Simmons, E. (2005). Predictors of organizational commitment among staff in assisted living. The Gerontologist, 45(2), 196-205. https://doi.org/10.1093/geront/45.2.196

Stinglhamber, F., Marique, G., Caesens, G., Desmette, D., Hansez, I., Hanin, D., \& Bertrand, F. (2015). Employees' organizational identification and affective organizational commitment: An integrative approach. PLOS ONE, 10(4), e0123955. https://doi.org/10.1371/journal.pone.0123955 
Spector, P. (1997). Job satisfaction: Application, assessment, causes and consequences. Thousand Oaks, CA. Sage Publications.

Suman, S., \& Srivastava, A. K. (2012).Antecedents of organisational commitment across hierarchical levels. Psychology and Developing Societies, 24(1), 61-83.https://doi.org/10.1177/097133361102400103

Shropshire, J., \& Kadlec, C. (2012). I'm leaving the IT field: the impact of stress, job insecurity, and burnout on IT professionals. International Journal of Information and Communication Technology Research, 2(1), 6-16. Retrieved from http://www.esjournals.org

Syed, N., Saeed, A., \& Farrukh, M. Organization commitment and five factor model of personality: Theory recapitulation. Journal of Asian Business Strategy, 5(8). https://doi.org/ 10.18488/journal.1006/2015.5.8/1006.8.183.190

Tabachnick, B. G., \& Fidell, L. S. (2013). Using multivariate statistics. Boston: Pearson Education.

Tupes, E. C., \& Christal, R. E. (1992). Recurrent personality factors based on trait ratings. Journal of Personality, 60(2), 225-251. https://doi.org/10.1111/j.1467-6494.1992.tb00973.x

Thurstone, L. L. (1934). The vectors of mind. Psychological Review, 41(1), 1-32. https://doi.org/10.1037/h0075959

Uher, J. (2013). Personality psychology: Lexical approaches, assessment methods, and trait concepts reveal only half of the story-Why it is time for a paradigm shift. Integrative Psychological \& Behavioral Science, 47(1), 1-55. https://doi.org/10.1007/s12124-013-9230-6

Üngüren, E., \& Ehtiyar, R. (2016). Determination of the demographic variables predicting accommodation business employees organizational commitment and job satisfaction through CHAID analysis. Journal of Business Research - Turk, 8(2), 331-331. https://doi.org/10.20491/isarder.2016.182

United States Bureau of Labor Statistics. (2017). Occupational outlook handbook: Computer and informational technology occupations. Retrieved from https://www.bls.gov/ooh/computer-and-information-technology/home.htm

Vandenberghe, C., Bentein, K., Michon, R., Chebat, J.-C., Tremblay, M., \& Fils, J.-F. (2007). An examination of the role of perceived support and employee commitment in employee-customer encounters. Journal of Applied Psychology, 92(4), 1177-1187. https://doi.org/10.1037/0021-9010.92.4.1177

Von Rimscha, M. B. (2015). The impact of working conditions and personality traits on the job satisfaction of media professionals. Media Industries.Journal, 2(2). https://doi.org/10.3998/mij.15031809.0002.202

\section{Copyrights}

Copyright for this article is retained by the author(s), with first publication rights granted to the journal.

This is an open-access article distributed under the terms and conditions of the Creative Commons Attribution license (http://creativecommons.org/licenses/by/4.0/). 